\title{
Effect of water on the caking properties of different types of wheat flour
}

\author{
Hasmadi, M. \\ Food Technology and Bioprocessing Program, Faculty of Food Science and Nutrition, Universiti Malaysia \\ Sabah, 88400 Kota Kinabalu, Sabah, Malaysia
}

Article history:

Received: 31 July 2020

Received in revised form: 27

August 2020

Accepted: 14 October 2020

Available Online: 10 January

2021

\section{Keywords:}

Wheat flour,

Caking index,

Stickiness

\section{DOI:}

https://doi.org/10.26656/fr.2017.5(1).412

\begin{abstract}
In this study, powder flow analyser was used to determine the caking characteristics of a different type of wheat flours. Besides the flour type as a variable, three levels of water percentage $(12.5,18.5$ and 30 (\% w.w.b)) were also tested. The presence of water with the powder plays a significant role in the way the cereals powders pack and flow. Although tapped bulk densities did not vary much, the water had a significant impact on the powder caking strength. The results showed that these parameters were increased significantly as the water level increased for all flours. It is also revealed that different flours cake differently when different levels of water are added. At the highest water content, the caking increase markedly for the flours. Plasticisation by addition of water to the food powder is believed to be the essential factor determining the results obtained.
\end{abstract}

\section{Introduction}

Stickiness in foods is generally an undesirable property because it can cause difficulty in processing, handling, mixing and storage of food materials (Ellen et al., 2019; O'Neill et al., 2019). Papadakis and Bahu (1992) used cohesion (particle-particle stickiness) and adhesion (particle-wall surface stickiness) terms to describe stickiness. Cohesion was defined as an internal property of a powder and is a measure of the forces holding the particles together, whereas adhesion in an interfacial property and is a measure of the forces holding the particles to the surface of another material. Boonyai et al. (2004) described the mechanisms of stickiness as being divided into five groups, namely intermolecular and electrostatic forces, mobile liquid bridges, immobile liquid bridges, solid bridges and mechanical interlocking. It has been shown that the major cause of stickiness in amorphous powders is water plasticisation of particle surfaces. This concept can be explained by the relationship between glass transition ( $T g$ ) and water content. The $T g$ decreases as water content increases and thus increased the stickiness (Roos and Karel, 1991).

A familiar example of stickiness is caking during storage (Zafar et al., 2017). A strict definition of caking is difficult to formulate because changes in a particulate system depend on temperature, moisture and position within the powder. It will involve many different stages, including; bridging, agglomeration, compaction and liquefaction (Aguilera et al., 1995). Bridging is the initial stage in caking that occurs as a result of surface deformation and sticking at contact points between particles. Agglomeration is a later stage involving an irreversible consolidation of bridges whereas compaction is a more advanced stage, associated with a pronounced loss of integrity as a result of the thickening of interparticle bridges owing to flow, reduction of interparticle spaces, and deformation of particle clumps under pressure. In the final stage of caking, interparticle bridges disappear as a result of sample liquefaction and extensive flow owing to high moisture content (Aguilera et al., 1995). There are various quantitative methods to identify the caking phenomena such as flowability, angle of repose, interparticle cohesion, size distribution and particle morphology.

The standard method to characterise flow properties of solid materials is by shear testing using the Jenike Shear Cell. Many techniques and tests exist to measure the flowability of the bulk solids, and these include the Jenike's shear cell, annular shear cells, triaxial tester, true biaxial shear tester, to name a few (Thakur et al., 2014). Most of the testers are suitable only for the dry solid materials. The powder flow analyser (PFA) was introduced by Stable Micro Systems, UK to solve the need for an instrument giving rapid, objective, repeatable and sensitive measurements for the assessment of dry and wet powder flow properties by using a sensitive 
force transducer to monitor the reactive forces caused by the sample displacement in a controlled manner. In this study, the caking of wheat flours was investigated with particular emphasis on the influence of the presence of different levels of moisture content using the rheometer powder flow analyser. The tapped bulk density, particle size distribution and granules' morphology of the wheat flours were also measured.

\section{Materials and methods}

The measurements of caking strength were made and evaluated against data related to particle characterisation. Soft wheat flour (WF) was obtained from Smiths Flour Mills (UK). Viking strong flour (VK), Canadian flour (high $(\mathrm{CH})$ and low grind $(\mathrm{CL})$ ) and English bread flour (EB) were kindly supplied by Campden and Chorleywood Food Research Association (CCFRA) (United Kingdom). The material's water content was adjusted to three levels; 12.5, 18.5 and $30.0 \%$ respectively, on material wet basis. The specifications of the flour are given in Table 1.

\subsection{Powder flow analysis sample preparation}

Flours (soft wheat, Viking, Canadian and English bread) were mixed with water using the dough mixer attachment with a Kenwood mixer (KM200, UK) for 10 mins at a constant speed. After thorough mixing, samples were collected in aluminium bags and sealed tightly, then left for $8-10 \mathrm{hrs}$ to ensure homogenous water distribution before measurements. Three water content, $12.5,18.5$ and 30 (\% w.w.b) were used.

\subsection{Laser diffraction particle size analyser}

The particle size was determined for this work using a laser diffraction particle size analyser LS $13 \quad 320$ (Beckman Coulter, Inc., Fullerton, CA), equipped with an optical bench and a Universal Liquid Module to measure the size distribution of particles suspended in propanol-2. The analysis was conducted at a pump speed setting of $50 \%$. The result is a particle size distribution displayed as volume $\%$ in discrete size classes. All measurements were obtained in triplicate.

\subsection{Tapped bulk density}

The tapped bulk density was measured according to Kumar et al. (2002) with slight modification. The powder was filled to a known volume in a cylinder and lightly tapped 20 times on the hard table surface. The volume was then read directly from the cylinder and used to calculate the bulk tap density according to the relationship; mass/volume.

\subsection{Polarised light microscopy}

The morphology of starch the granules was visualised and recorded with a polarised light microscope (Wild Leitz GmbH, Wetzlar, Germany) fitted with a digital camera. Dry samples powders (125$250 \mathrm{~mm}$ ) were placed on a standard glass microscope slide, and a dropped of water was carefully added. They were then covered with coverslip. Visual magnifications were $40 x$.

\subsection{Flow behaviour characterisation}

Caking strength was measured using powder rheometry (texture analyser, TA-XT2 Plus, Stable Micro System, UK). The samples were packed in the container of the measuring vessel (borosilicate glass) and the apparent volume of the packed sample was fixed at 140 $\mathrm{ml}$. A rotor was introduced into the packed powder sample using rotor blade with diameter and height of 10 $\mathrm{mm}$ and $48 \mathrm{~mm}$, respectively, with a rotation speed of 20 $\mathrm{rpm}$ and a vertical velocity of $50 \mathrm{~mm} / \mathrm{s}$.

\subsection{Statistic analysis}

Statistical differences were determined by an analysis of variance (ANOVA), with mean separations performed by the Tukey HSD test, using SPSS version 23. Mean and standard deviations were calculated for each measurement.

\section{Results and discussion}

\subsection{Particle size distribution}

The stickiness and caking behaviour of powders can be related to the physical forms and dimensions of the particulates (O'Donoghue et al., 2019). Particle size has been considered as one of the most important physical properties which affect the flowability of powders

Table 1. Wheat flours used in the studies

\begin{tabular}{lcc}
\hline \multicolumn{1}{c}{ Type of flour } & Source & Specification \\
\hline Viking strong flour & Whitworth Bro. Ltd., UK & $13.5 \% \mathrm{MC}, 11.5 \% \mathrm{PC}$ \\
Canadian flour (high grind) & CCFRA & $14.9 \% \mathrm{MC}, 13.5 \% \mathrm{PC}$ \\
Canadian flour (low grind) & CCFRA & $14.9 \% \mathrm{MC}, 13.5 \% \mathrm{PC}$ \\
English bread flour & CCFRA & $14.0 \% \mathrm{MC}, 12.0 \% \mathrm{PC}$ \\
Resolute wheat flour & Smith Flour Mills (UK) & $14.0 \% \mathrm{MC}, 11.0 \% \mathrm{PC}$ \\
\hline MC = moisture content, PC = protein content
\end{tabular}


(Hasmadi et al., 2020). Teunou et al. (1999) reported that powders with particles size larger than $200 \mu \mathrm{m}$ are free-flowing, while fine powders are subject to cohesion and their flowability is more complicated. Particle size distribution is important in determining the way powders will flow or pack; therefore, the materials' (wheat flours) particle size distribution was measured. A result is shown in Figure 1. Particle size distributions are displayed as volume $\%$ in discrete size classes. The results show that the size distribution of various flours centred at two different peaks. The first peak was observed at $110.9 \mu \mathrm{m}$ for Viking flour and English bread flour while Canadian high and low grind, as well as wheat flour, were observed at $121.8 \mu \mathrm{m}$. The second peak was observed at 948.3, 716.8, 653.0, 716.8 and $948.3 \mu \mathrm{m}$ for Viking flour, English bread flour, Canadian flour (high grind), Canadian flour (low grind) and wheat flour, respectively.

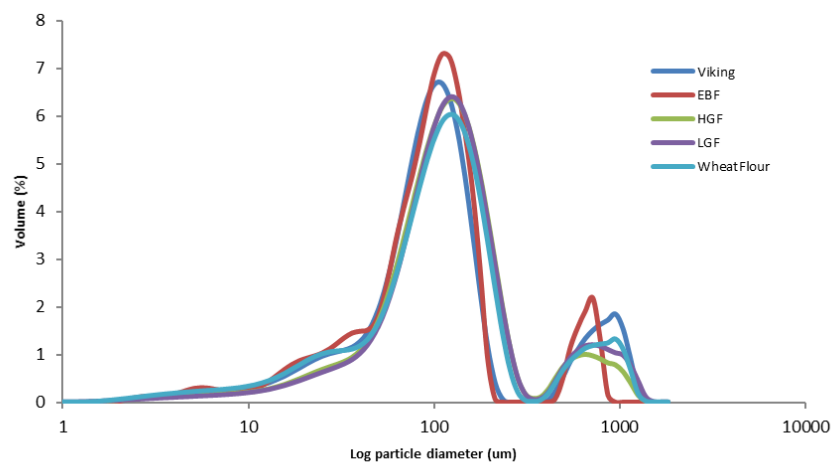

Figure 1. Particle size distribution for Viking, English bread (EBF), Canadian high grind (HGF), Canadian low grind (LGF) and soft wheat flours (WheatFlour)

\subsection{Microstructure of flour under light microscopy}

Light microscopy was employed for characterising wheat flours with respect to appearance, shape and size of the granules. The results showed that soft wheat flour possesses similar characters (size and shape) with other types of wheat flour where it came from the same source (Figure 2). Variability of the shape of food powders' particles may influence their bulk density property (Mamat et al., 2010).

\subsection{The effect of water on flours density}

Bulk density is defined as the mass of particles that occupies a unit volume of a container. Bulk density of granular solids and powders mostly depends on particle size, moisture, chemical composition, handling and processing operations. Tap density is the bulk density after a volume of powder has been tapped or vibrated under specific conditions. It can also be regarded as a compact density (Barbosa-Canovas et al., 2005). The tapped bulk density for different types of flour, with various water levels, is shown in Figure 3. The densities

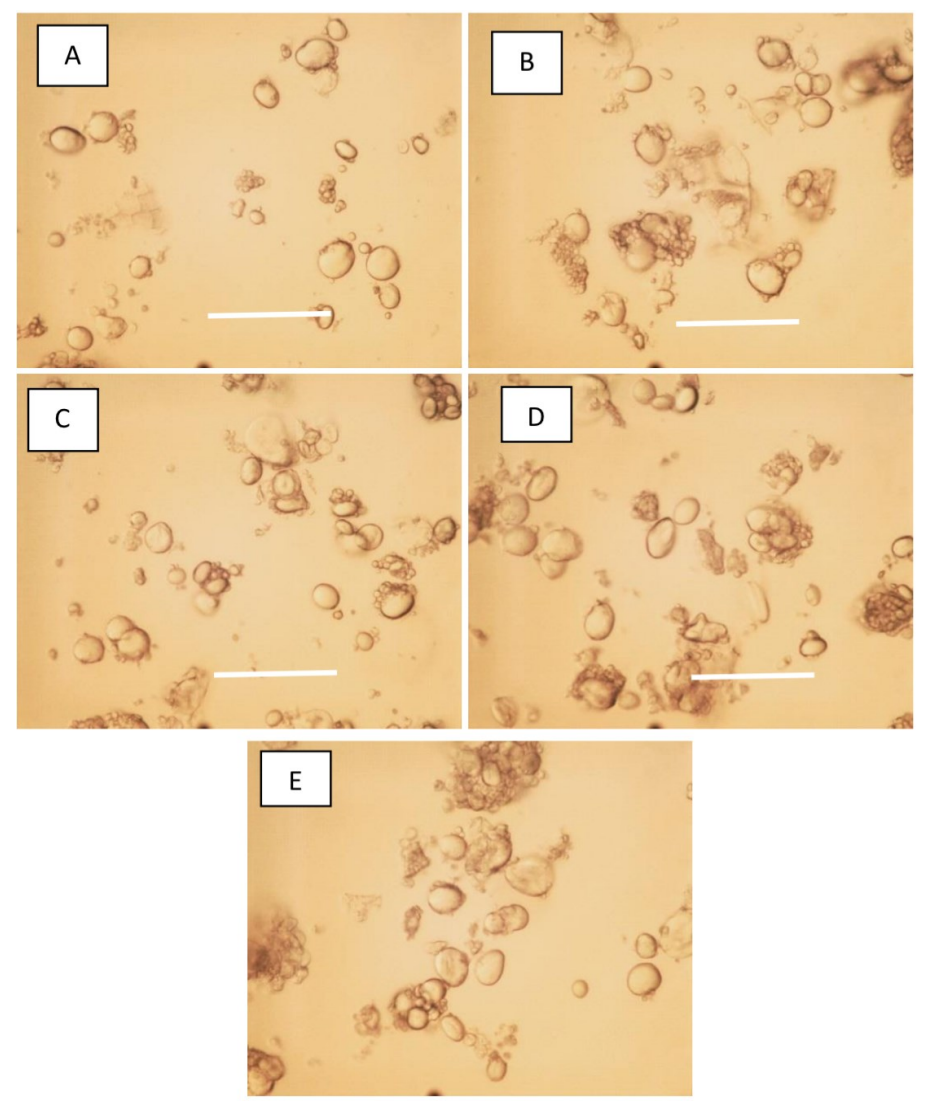

Figure 2. Soft wheat flour (A), Canadian high grind (B), Canadian low grind (C), English bread low (D) and Viking strong flour (E) observed under light microscope (magnification 40x). Samples were dispersed in distilled water. $\mathrm{Bar}=100 \mu \mathrm{m}$

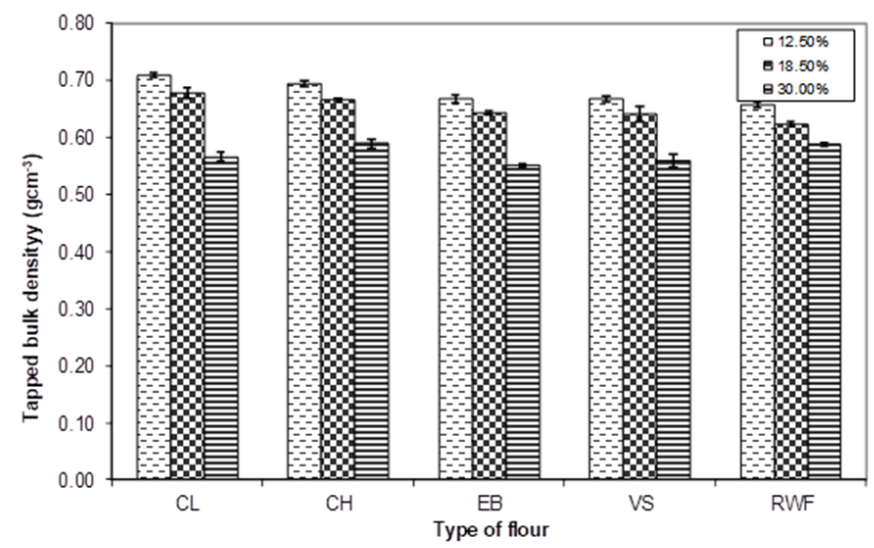

Figure 3. Bulk density of different flours at three water levels; namely $12.5,18.5$ and $30.0 \%$. Error bars are \pm one standard deviation of three replicates. Flours abbreviation: CL Canadian low grind, $\mathrm{CH}$ - Canadian high grind, EB - English bread, VS - Viking strong, RWF - Resolute wheat

show a decreasing trend with the increase of water level for all samples and they were significantly different between different water levels; $15.0,18.5$ and $30.0 \%$, for each flour studied. At the higher water level, powders were less compact as compared to the low water level. This is as expected as at higher water level where powder granules can agglomerate to form a clumpy powder and produce more voids between them.

Moisture content is one of the major factors affecting food powder bulk density as well as surface activity and 
cohesion. Many food powders are highly hygroscopic, and therefore high moisture contents would result in lower loose bulk densities. In wet powders, or upon exceeding the relative humidity $(\mathrm{RH})$ at which capillary condensation may take place (frequently at $\mathrm{RH}>0.6$ $0.7)$, porosity increases, or bulk density decreases as compared to the dry condition (Schubert, 1987).

Moreyra and Peleg (1980) reported that moist or cohesive powders could show a lower density. This is the result of the formation of an open bed structure that is supported by inter-particle forces and liquid bridges (Peleg et al., 1973). Since such open structures are weak and unstable, they are expected to collapse under relatively small stresses. Ortega-Rivas (2009) reported that bulk density of food powders depends on the combined effect of interrelated factors, such as the intensity of attractive interparticle forces, the particle size and the number of contact points. He concluded that a change in any of the powder characteristics might result in a significant change in the powder bulk density.

\subsection{The effect of water on flour caking properties}

Water content plays important roles in determining the caking and cohesion properties of flours. At low water content $(12.5 \%)$, all powder particles are freeflowing but at high water level $(30 \%)$, the particles powder turned to agglomerates. Caking strength (CS) and cohesion index (CI) of wheat flour powders at various water levels is shown in Table 2, and physical appearance images of Canadian high grind are shown in Figure 4. Results obtained showed that CS increased as the water level increased from 12.5 to $30 \%$ for all samples. This is in agreement with Abu-Hardan and Hill, (2010). All powders measured to produce a very strong cake formation (CS) at 30\% of water level and were significantly different from values of 12.5 and $18.5 \%$ water level (Table 2). Increased water level from 12.5 to $18.5 \%$ showed no significant differences for Canadian low, English low and Viking strong flour. At $30 \%$ of water level, CI values showed similar trends with CS except for Resolute wheat flour.
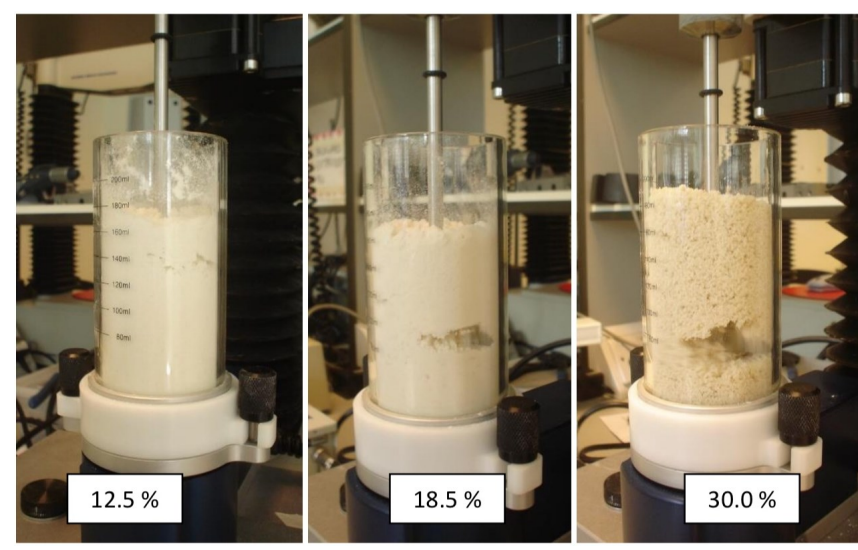

Figure 4. Images of Canadian high grind flour at three water levels, $12.5,18.5$ and $30.0 \%$ respectively

eISSN: 2550-2166
Caking strength for all samples showed a very high value at $30.0 \%$ water level compared to 12.5 and $18.5 \%$. Canadian high and Canadian low gave the highest values and were not significantly different from each other but were significantly different from the other flours. Resolute flour had the lowest CS value. The amount of protein content in the flour thought to be a factor contributing to this result. Different types of flour contained various protein contents. Canadian high, Canadian low, English low and Viking flours are strong flours and used in bread manufacture. The protein content of these flours is about $12-13.5 \%$, whereas Resolute flour is soft wheat flour with a protein content about $10-11 \%$. As discussed earlier, protein content present in the flour would influence water absorption, thus influencing the caking strength of these powders.

Table 2. Caking strength and cohesion index of various wheat flours at different water level

\begin{tabular}{ccc}
\hline Wheat flour & Moisture (\%) & Caking index \\
\hline Canadian low & 12.5 & $35.53 \pm 2.69^{\mathrm{a}}$ \\
grind & 18.5 & $41.06 \pm 5.82^{\mathrm{b}}$ \\
& 30 & $595.81 \pm 58.55^{\mathrm{c}}$ \\
\hline Canadian high & 12.5 & $22.59 \pm 1.16^{\mathrm{a}}$ \\
grind & 18.5 & $54.54 \pm 9.96^{\mathrm{b}}$ \\
& 30 & $517.94 \pm 3.15^{\mathrm{c}}$ \\
\hline English bread & 12.5 & $29.49 \pm 1.45^{\mathrm{a}}$ \\
flour & 18.5 & $43.37 \pm 8.85^{\mathrm{b}}$ \\
& 30 & $345.51 \pm 27.32^{\mathrm{c}}$ \\
\hline Viking strong & 12.5 & $20.80 \pm 3.76^{\mathrm{a}}$ \\
flour & 18.5 & $46.67 \pm 14.16^{\mathrm{b}}$ \\
& 30 & $384.31 \pm 18.54^{\mathrm{c}}$ \\
\hline Resolute wheat & 12.5 & $29.35 \pm 4.83^{\mathrm{a}}$ \\
flour & 18.5 & $70.78 \pm 5.84^{\mathrm{b}}$ \\
& 30 & $306.32 \pm 26.41^{\mathrm{c}}$
\end{tabular}

Means with different letters in each column for different types of flour are significantly different $(\mathrm{p}<0.05)$

When comparing between starch and flour powders, CS obtained for flour at $30 \%$ of water level were much higher and significantly different when compared with CS for starch powders (Mamat et al., 2012). Flour protein and damaged starch in the flour are believed to be the factors contributing to the results obtained (Mamat and Hill, 2018). According to Manley (2000), protein absorbed 2 units of water per unit of protein and damaged starch absorbed 1 unit of water per unit of starch; meanwhile native starch absorbed 0.33 unit water per unit starch. Flour contains higher protein content with amount ranged from $11-13.5 \%$ whereas starch contains less than $1 \%$. A hydrated protein formed films and sticky elastic mixtures that produced a strong cake bed when compacted with rotor blade during the measurement, therefore, higher force required to cut 
through.

Besides higher protein content, flour also contains higher damaged starch. During milling, some starch granules are mechanically damaged and loss of integrity of the crystalline structure that has a profound effect on the water absorption property of the flour (Manley, 2000). Canadian low, Canadian high, English bread and Viking strong flours are hard wheat flour with $6-8 \%$ of damaged starch whereas Resolute flour is soft flour with $3-5 \%$ damaged starch. The terms low and high refer to the amount of damage inflicted on the starch during milling. Damaged starch greatly affects starch properties. These granules which have an increased ability to bind water and much greater water retention capacity could take up water with the loss of amylose from the granule to form sticky masses.

Another suggestion of strong caking formation in the flour with $30.0 \%$ of water as compared to starch with the same water level is the presence of pentosans in the flour. According to Roman-Gutierrez et al. (2002), soft wheat flour and hard wheat flour contained about 1.51 and $1.76 \%$ (dry basis) of total pentosans respectively. Due to high water capacity binding, pentosans can absorb large amounts of water, up to $10-11$ times their weight, therefore, contributed to strong cake formation of flour powders.

\section{Conclusion}

The presence of water with the powder plays an important role in the way the cereals powders pack and flow. Different types of flour showed various caking properties. Particle size distribution, granules morphology and protein content are factors contributed to the results obtained. It was expected that the differences in the starch damage levels between the Canadian flours would make a notable difference to the powder flow values.

\section{Conflict of interest}

The authors declare no conflicts of interest.

\section{References}

Abu-Hardan, M. and Hill, S.E. (2010). Handling properties of cereal materials in the presence of moisture and oil. Powder Technology, 198(1), 16-24. https://doi.org/10.1016/j.powtec.2009.10.002

Aguilera, J. M., del Valle, J.M. and Karel, M. (1995). Caking phenomena in amorphous food powders. Trends in Food Science and Technology, 6(5), 149155. https://doi.org/10.1016/S0924-2244(00)89023-8

Barbosa-Canovas, G.V., Ortega-Rivas, E., Juliano, P. and Yan, H. (2005). Food powders: Physical properties, processing, and functionality. New York, USA: Kluwer Academic Publisher.

Boonyai, P., Bhandari, B. and Howes, T. (2004). Stickiness measurement techniques for food powders: a review. Powder Technology, 145(1), 3446. https://doi.org/10.1016/j.powtec.2004.04.039

Ellen, E., Martin, N., Susan, G.S. and Arntfield, D. (2019). Differentiating between tackiness and stickiness and their induction in foods. Trends in Food Science and Technology, 88, 290-301. https:// doi.org/10.1016/j.tifs.2019.03.014

Hasmadi, M., Noorfarahzilah, M., Noraidah, H., Zainol, M.K. and Jahurul, M.H.A. (2020). Functional properties of composite flour: a review. Food Research, 4(6), 1820-1831. https://doi.org/10.26656/ fr.2017.4(6).419

Kumar, V., Reus-Medina, M.D.L. and Yang, D. (2002). Preparation, characterisation, and tabletting properties of a new cellulose-based pharmaceutical aid. International Journal of Pharmaceutics, 235(12), 129-140. https://doi.org/10.1016/S0378-5173(01) 00995-4

Mamat, H. and Hill, S.E. (2018). Structural and functional properties of major ingredients of biscuit. International Food Research Journal, 25(2), 462471.

Mamat, H., Abd Hamid, A. and Hill, S.E. (2012). Characterization of cohesive cake formation and stickiness of starches at various water levels in the presence of palm oil and palm oil fractions. International Journal on Advanced Science, Engineering and Information Technology, 2(4), 319324. https://doi.org/10.18517/ijaseit.2.4.213

Mamat, H., Abu Hardan, M.O. and Hill, S.E. (2010). Physicochemical properties of commercial semisweet biscuit. Food Chemistry, 121(4), 1029-1038. https://doi.org/10.1016/j.foodchem.2010.01.043

Manley, D. (2000). Technology of Biscuits, Crackers and Cookies. 3rd ed. Cambridge, UK: Woodhead Publishing Limited. https://doi.org/10.1201/ NOE0849308956

Moreyra, R. and Peleg, M. (1981). Effect of equilibrium water activity on the bulk properties of selected food powders. Journal of Food Science, 46(6), 19181922. $\mathrm{https}: / /$ doi.org/10.1111/j.13652621.1981.tb04519.x

O'Donoghue, L.T., Haque, M.K., Kennedy, D., Laffir, F.R., Hogan, S.A., O'Mahony, J.A. and Murphy, E.G. (2019). Influence of particle size on the physicochemical properties and stickiness of dairy powders. International Dairy Journal, 98, 54-63. 